Nuclear Criticality safety of the Fuel clear Criticality Safely of laity at
Element Fabricant massachusetts
Attleboro, Mass

J.T. Thomas 
ORNL/CSD/TM-SS

Distribution Catezory

UC-46

Contract No. W-7405 eng 26

COMPUTER SCIENCES DIVISION

NUCLEAR CRITICALTTY SAFETY OF THE FUEL ELEMENT FABRICATION

FACILTY AT ATTLEBORO, MASSACHUSETTS

\section{J. T. Thomis}

Date Publ18hed - June, 1978

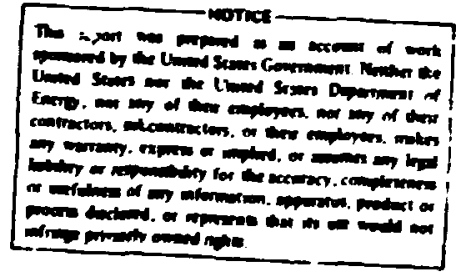

notice This documant contains information of a preliminary nature. It is eubject ro revision of forrertion ard therefore coes not represent a final report.

UNION CARBIDE CORPORATION, NUCLEAR DIVISION operating the

Oak Ridge Gaseous Diffusion Plant . Oak Ridge National Laboratory

Oak Ridge Y.1z Plant - Paducah Gaseous Diffusion Plant

for the

DEPARTMENT OF ENERGY 


\section{T. WLE OF CONTENTS}

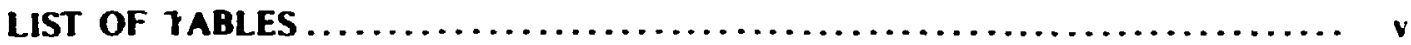

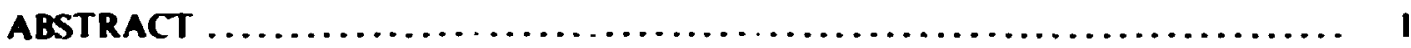

INTRODUCTION ................................................. I

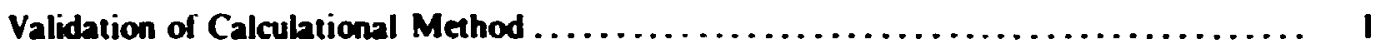

Application of Method $. \ldots \ldots \ldots \ldots \ldots \ldots \ldots \ldots \ldots \ldots \ldots \ldots \ldots \ldots \ldots \ldots \ldots \ldots, \quad 3$

Fuel plates $\ldots \ldots \ldots \ldots \ldots \ldots \ldots \ldots \ldots \ldots \ldots \ldots \ldots \ldots \ldots \ldots \ldots \ldots \ldots \ldots \ldots, \quad 3$

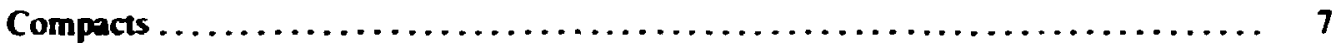

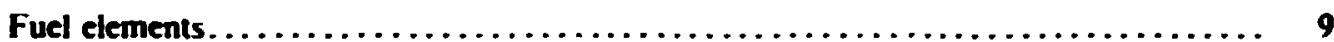

Discussion .................................................. II

Cunclusions.................................................

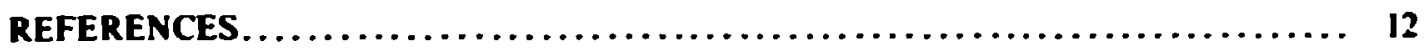




\section{LIST OF TABLES}

Table

Page

1. Description of fuel plates and atom number densities.................... 2

2. Calculated $k$-eff for critical experiments with ORR and SPERT-D fuel etements........................................... 3

3. BNL fuet plate description $\ldots \ldots \ldots \ldots \ldots \ldots \ldots \ldots \ldots \ldots \ldots \ldots \ldots \ldots \ldots \ldots \ldots, 4$

4. Calculated $k$-eff of concrete retlected arrays of storage boxes having uranium-aluminum plates bearing $\sim 21$ \& U(93.2) per plate

5. Computed k-eff oi concrete reflected arrays of $8 \times 8 \times 8$ cardboard boxes with variable moderation conditions

6. Compuled $k$-eff of concrete reflected arrays of 912 boxes of plates arranged in a $10 \times 10 \times 10$ cuboidal array with variable moderating conditions.

7. Description of typical HFBR compact

8

8. Calculated $k$-eff of stainless steel trays each containing 24 fuel plate compacts arranged in cuboidai arrays reflected by $30.5-\mathrm{cm}$-thick water

9. Calculated k-eff of two neutron interacting assemblies of SPERT-D fuel elements separated by is cm.

10. Calculated $k$-eff of water reflected arrangements of HFBR fuel elements 


\title{
NUCLEAR CRITICALITY SAFETY OF THE FUEL ELEMENT FABRICATION FACILTY AT ATTLEBORO, MASSACHUSTTTS
}

\author{
J. T. Thomas
}

\begin{abstract}
ADSTRACT
The Altieboro Facility produces fuet elements for the ORR and itre HFIR rectors at the 'ak Ridge National Laboratory and for the HFBR reactor at the Brookmice: Natjonai Laburatory. It is proposed to utilize the criticality indicator system. (CI) as a merbod for nuclear criticaliey control at the Altkboro fuel element fabrication facitity. Application of the methoe requires an evaluation be made of the effect of hydrogenoss moderation on the potential neutron muhiplication factor of operations. Analyses are given which confirm the applicability of ti.e CI syseem under credible normal and possible abnorral contingencies. It is also shown that no significant neutron multiplication occurs during normal operations and that a $k_{\text {ett }}$ not exceeding 0.5 may be expected for abnermal conditons.
\end{abstract}

\section{INTRODUCTION}

Fuel elements are fabricated at the manufacturing facility in Alledso, Mastachusetts, opera:ert by the Texas Instruments Corporation. Elements are produced for the Oak Ridge Naional Laboratory (ORNL) for use in the HFIR and the ORR reactors and for the Rrookhaven vational Laboratory (BNL) for use in the HFBR reactor. The Criticality Indicator system (CI) described in the Nuclear Safety Guide' provides the bases for control of nuclear critinality safety in the plant. Th: system controls the neutron interaction among subcritical quantities of fissiorable materials in the absence of intervening hydrogenous moderation. The Nuclear Safety Guide recommends that. when hydrogenous moderation is a credille possibility. the effects of the moderation on the system be investigated by a validated calculational method. Since the fire protectivn capability of the plam incorporates a water sprinkler system, it is necessary 10 assess the eifect on the degree of subcriticality of operations caused by possible moderation within areas and materials. The 'silowrag analyses performed by a validated alculational method evaluate the effert of mnderation on operations with materials in the form used in the plant.

\section{Vaidation of Colculational Method}

Critical experiments with ORR and BSR fuel elements vere performxd ai the Oak Ridge Critical Experiments Facility (ORCEF) and reported in 1958. A series of measurcments chisb!ished that a minimum of 15 elements containing $168 \mathrm{~g}$ of ${ }^{23} \mathrm{U}$ each in a $4 \times 4$ matrix with a corner 

position vacant would be critical if the spacing between elements were $0.503 \mathrm{~cm}(0.2 \mathrm{in})$. Another measurement used 12 of the $168 \mathrm{~g}$ elements with four elements having 1408 of ${ }^{233} \mathrm{U}$ in 1 wo different atrangements in a $4 \times 4$ pattern with zero spacing.

Critical experiments with the SPERT-D fuel elements were also conducted at the ORCEF and reported' in 1965. These elements contain $306.5 \mathrm{~g}$ of ${ }^{235} \mathrm{U}$. The SPERT-D phtes contain 57\% more ${ }^{23} U$ than the ORR plates and both were fabricated* with a uranium-aluminum alloy clad in aluminum.

The dimensions of the fuel region in the plates and the atom number densities are given in Table 1. The experiments were calculated with the KENO Mante Carb" code using the Hansen-Roach' 16-group neutron cross section sets. The arrangement of the fuel elements and the calculated $k_{e f t}$ are presented in Table 2 The influence of cross section set selection on the calculated hetl was explored by repeating the calculations using the BONAMI option for cross section tratment in the AMPX system". The results of these tests suggest that the normel procodure for determining cross section sets to be used. i.e., on tive basis of $\sigma_{m}$ could result in at most a negative bias of 0.02 in $k_{\text {eff }}$ with an uncertainty of \pm 10 . This implies that systems calculated to have a $k_{\text {ent }}$ of 0.98 should be regarded as having potential for criticality.

Table 1. Description of fuel plates and aton number densities

\begin{tabular}{|c|c|c|c|}
\hline Element & ORR & $\underline{O R R}$ & SPERTT-D \\
\hline :35U per elenent, 9 & 168 & 140 & 306.5 \\
\hline No. of plates & 19 & 19 & 22 \\
\hline \multicolumn{4}{|c|}{ Fuel Region Otmensions, $\mathrm{C}$} \\
\hline width & \multicolumn{2}{|c|}{6.2865} & 6.2332 \\
\hline length & \multicolumn{2}{|c|}{59.8348} & 60.9600 \\
\hline thickness & \multicolumn{2}{|c|}{0.0698} & 0.0508 \\
\hline \multicolumn{4}{|c|}{ Atnm Densities $\left(\times 10^{-24}\right)$} \\
\hline 235 & $8.61079-4$ & $7.18747-4$ & $1.82954-3$ \\
\hline 210 & $6.22380-5$ & $5.19507-5$ & $1.33875-4$ \\
\hline${ }^{27}$ AI & $4.14310-2$ & $4.21440-2$ & $5.53596-2$ \\
\hline \multicolumn{4}{|c|}{ Plate Dimensions, $\mathrm{cm}$} \\
\hline width & \multicolumn{2}{|c|}{7.11708} & 6.8682 \\
\hline length & \multicolumn{2}{|c|}{62.5475} & $63.81 \% 5$ \\
\hline thickness & \multicolumn{2}{|c|}{0.127} & 0.1524 \\
\hline
\end{tabular}

-Current operations at ORR use an nxide of uranium in place of the metal alloy. 
Tabie 2. Calculated $k$-eff for criticai experiments with ORR and JPERT-D fuel elewents

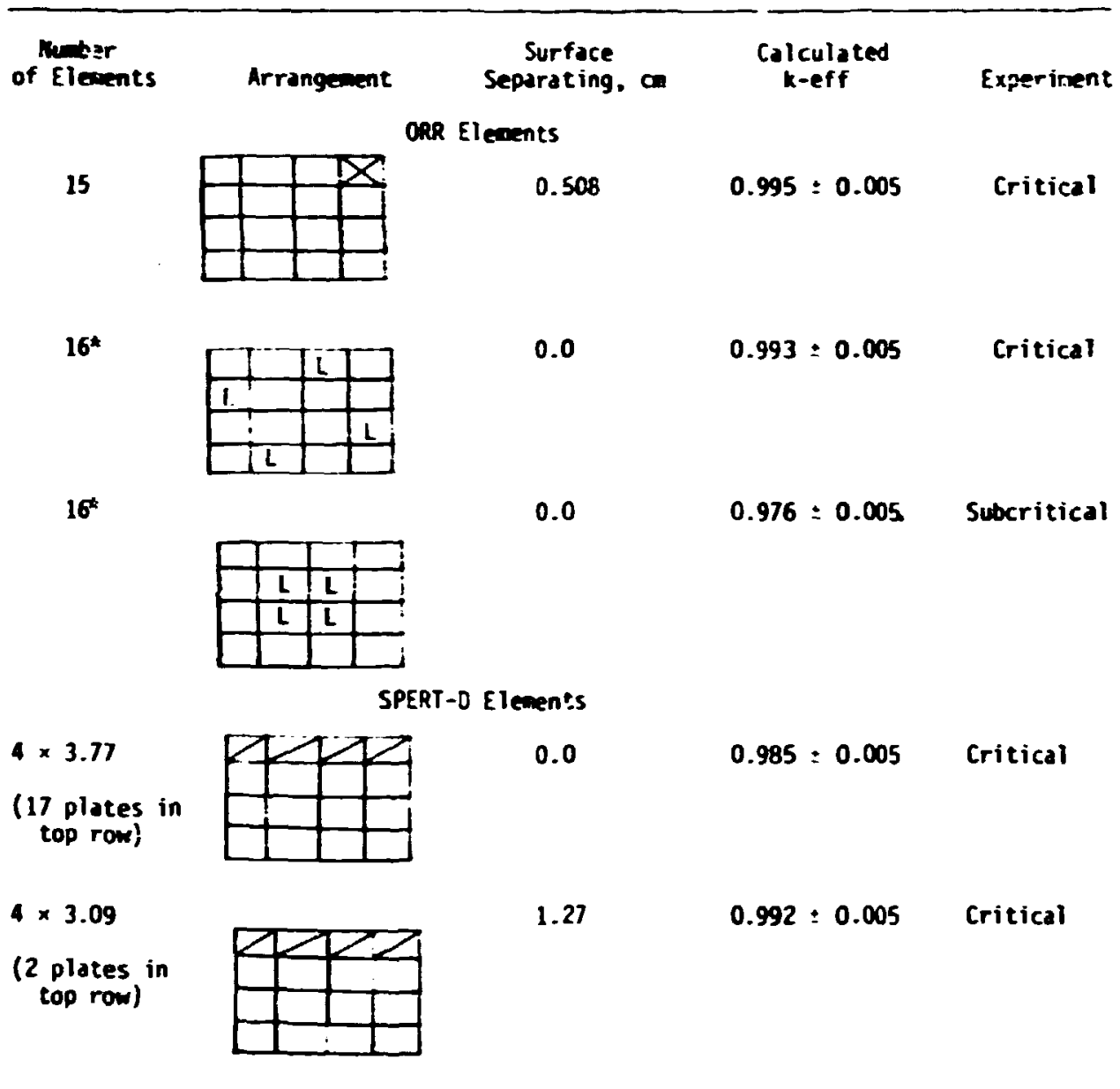

¿L designates $140 \mathrm{~g} / \mathrm{element.,} \mathrm{remaining} \mathrm{are} 168$ g/elements.

\section{Fuel plates}

\section{Application of Method}

The BXI. fuel plates have a larger uranium loading than the elements produced for ORNI. The following analyses utilize the characteristics of the B.VI. element plates as described in Table 3. A waterproof cardbiard box $(35.6 \times 17.8 \times 6 \mathrm{~cm}$. nominal) having a mass of $1.4 \mathrm{~kg}$ is used 10 transfer and store the fuel plates. The plates are arranged in a $3 \times 8$ matrix within the box and are separated by sheets of polyvinylchloride (CH:CHCI. at $\rho=0.9016 \mathrm{~g} \mathrm{~cm}$ ) for physical protection. There is approximately 800 grams of PVC per box as sev in shects, each about $0.06 \mathrm{~cm}$ in thickness. A hox does prevent moderation between plates within the box: however. such intemal moderation is examined. Storage of boxes is in separated lincar arrays located along the outer boundarics of large operationa! areas $(12 \times 15 \mathrm{~m}$. typically). The foors are of concrete and the building of light structure. A consenalive representation is is, coalesce all the storage arrays into a cuboidal 
Table 3. Bn fuel plate description

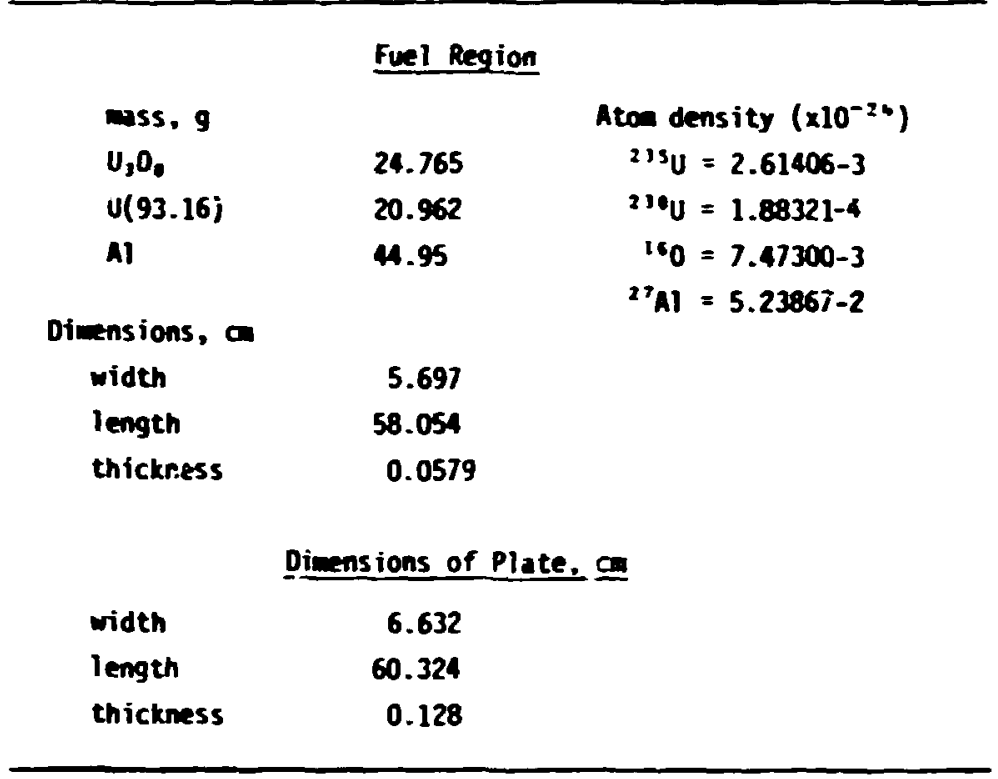

arrangement and to surround the resulting array with a closely fitting reflector of concrete $40.6 \mathrm{~cm}$ thick. This results in minimizing neutron leakage from the materials, enhancing neutron coupling among boxes and maximizing neutron reflection of the arrays. There are about two hundred box locations in the plant; however. the CI system specifies subcriticality for arrays of boxes two orders of magnitude greater than those in the plant. Analysis of larger arrays :han anticipated rep.esents a greater material ioventory than is actualty present, results in larger $k_{\text {eff }}$ values than may be reasonably expected, and validates the generic bases of the $\mathrm{Cl}$ system.

Calculations of the cuboidal arrays are presented in Table 4 as a function of the number of boxes, of the water density in and out of the boxes, and for the cardboard and a proposed aluminum box of the same dimensions but with $0.09-\mathrm{cm}$-thick walls. The code input used the aluminum box dimensions, and representation of the cardboard in this region was at a greater than normal density to maintain the cardboard mass. This perturbation has no significant effect on the calculated $k_{\text {efl. }}$ The first four entries of the table compare the effect of the cardboard and aluminum boxes and their internal moderation by low density water. The $\mathrm{N}=12^{3}$ arrays of the first entry show the cardboard as an effective moderator. The $N=8^{3}$ arrays with variable water density in the boxes explore the moderation effect on $k_{e f l}$ in the aluminum boxes. The fourth entry for $N=12^{3}$ shows the reduced effectiveness of the cardboard as a moderator when the boxes contain low density water. This indicates the array of cardboard boxes is near optimum moderation when water at $\rho=0.05$ is present. The remaining three entries of the table are with the boxes separated $\sim 30 \mathrm{~cm}$ horizontally, $\sim 12 \mathrm{~cm}$ vertically and in contact in the direction of plate length. This permits array moderation between boxes to be examined. 
Table 4. Calculated kefe of concrete reflected arrays of storage boxes

having urantum-aluminum plates bearing $221 \mathrm{~g}$ U(93.2) per plate

Boxes contain $3 \times 8$ merix of plates separated by polyrinylehloride.

\begin{tabular}{|c|c|c|c|c|c|c|c|c|c|c|}
\hline \multirow{3}{*}{$\begin{array}{l}\text { Separation } \\
\text { of Boxes } \\
\text { in Arrey }\end{array}$} & \multirow{3}{*}{\multicolumn{2}{|c|}{$\begin{array}{c}\text { Density of } \\
\text { water ( }\left(g / \mathrm{cm}^{\prime}\right) \\
\text { Oetween } \\
\text { Plates boxes }\end{array}$}} & \multicolumn{8}{|c|}{ Mumeer of boxes in Concrete Reflected Arrey } \\
\hline & & & \multicolumn{3}{|c|}{ Cordboard boxes } & \multicolumn{5}{|c|}{ Aluminum Boxes } \\
\hline & & & $\underline{12^{3}}$ & $16^{1}$ & $\underline{20^{\prime}}$ & $\underline{\theta^{3}}$ & $\underline{10}$ & $\underline{121}$ & $\underline{161}$ & 20! \\
\hline 0 & 0 & 0 & $0.131: 0.006$ & $0.838: 0.009$ & $0.905 \div 0.009$ & $0.518 \div 0.011$ & $\cdots$ & $0.627+0.007$ & $\cdots$ & $\cdots$ \\
\hline 0 & 0.005 & 0 & $\cdots$ & $\cdots$ & $\cdots$ & $0.580,0.011$ & 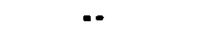 & $\cdots$ & $\because$ & $\cdots$ \\
\hline 0 & 0.010 & 0 & $\cdots$ & -- & -- & $0.827 \div 0.015$ & $\cdots$ & $\cdots$ & -- & $\because$ \\
\hline 0 & 0.050 & 0 & $0.973: 0.001$ & $\cdots$ & -- & $0.832: 0.013$ & $0.899 \div 0.010$ & $0.957 \div 0.007$ & $1.061=0.006$ & $1.133,0.000$ \\
\hline (a) & 0 & 0 & $0.496=0.001$ & $=$ & $\because$ & $\cdots$ & -- & $0.443 \cdot 0.006$ & $\because$ & $-\cdot$ \\
\hline (a) & 0 & 0.050 & $0.816 \div 0.006$ & $0.899=0.005$ & -. & $\cdots$ & -. & $0.808: 0.006$ & $\because$ & $\cdots$ \\
\hline$(0)$ & 0.050 & 0.050 & $0.834: 0.005$ & $\cdots$ & -- & $\cdots$ & $\cdots$ & $0.820: 0.006$ & 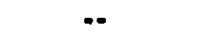 & $\cdots$ \\
\hline
\end{tabular}

(a) Centers of boxes spaced: $2 x, 66 \mathrm{~cm}, 2 y=42 \mathrm{~cm}$ and $28,60 \mathrm{~cm}, 1,9$. boxes in contact in 2 diraction. 
The fifth entry fer $x=12^{\circ}$ of the tau box materials resulk in kwer $k$ is than the first entry because of increased neutron kakage from the array and a reduced effect of the cariboard boxes as moderation to the array. The sixth and sel:-nith entries also evidence the raduced effect of the cardboard.

The boxes are sometimes open si work stations which would permit water io accumulate within the boxes. The neutron interaction between such units and storage units was explored by calculation of a concrete reflected array of $5 / 2$ boxe $\left(X=8^{3}\right)$. The description of this array designated the central 64 boxes $\left(X=4^{\prime}\right)$ as representing shose at work stations. The calculations are reported in Table 5 using the cardboard box. The $k_{\text {n:i }} s$ would be kess with aluminum boxes. The first two entries have low density water in the boxes at the work stations. and compare the compact array and the array of spaced boxes. The third entry reprisents the addition of low density water between all boxes of the array and results in the max:mum $k_{1}$ : observed. The fourth entry is the same as the third except the water density in the work statio 1 boxes has been increased to full density. The $k_{\text {." }}$ is not significantly different frum the third entry and is indicative of overmoderation of the array.

While the arrays of Table 5 do show the effect of low density water between boxes. there remains a yuestion of low density moderation occurring in larger void spaces. Calculation of arrays with brge voids containing water at $p=0.05 \mathrm{~g}$ ce would be wasteful. since a neutron traversing 2 io $4 \mathrm{~m}$ would have the same probability of survival as a neutron traversing 10 to $20 \mathrm{~cm}$ in water. In the interest of exploring a distance between work stations and between work stations and storage areas which may be significantly neutron-coupled. calculations were periormed on an $\mathrm{N}=10^{3}$ array described in the following. The first, second. fifth, sixth, ninth and tenth tiers of the ar: $s$ were filled with storage boxes. The central $4 \times 4$ cells in the third and eighth tiers of the $10 \times 10$ locations were void spaces and the remaining positions designated storage boxes. The boxes representing work stations were contained in the fourth and seventh tiers of the array. The central $2 \times 2$ boxes of the tiers were designated work stations, and these were surroundad by a ring of void cells. The remaining locations were labeled storage boxes. The arrangement results in 912 positions designated as storage, 8 designated as work stations, and 88 voided cells.

Table 5. Computed $k$-eff of concrete reflected arrays of $8 \times 8 \times 8$ cardboard ooxes with variable moderation conditions

\begin{tabular}{|c|c|c|c|c|c|}
\hline $\begin{array}{c}\text { 8ox } \\
\text { Spacing }\end{array}$ & \multicolumn{4}{|c|}{$\begin{array}{c}\text { Water Density, } 9 / \mathrm{cc} \text {, at } \\
\text { Work Station } \\
\text { Storage Between } \\
\text { Between }\end{array}$} & Array k-eff \\
\hline Contact & 0 & 0 & 0.05 & 0 & $0.670=0.006$ \\
\hline (a) & 0 & 0 & 0.05 & 0 & $0.438=0.006$ \\
\hline (a) & 0 & .05 & 0.05 & 0.05 & $0.68 !=0.605$ \\
\hline (a) & 0.05 & .05 & 1.0 & 0.05 & $0.656=0.006$ \\
\hline
\end{tabular}

(a) Boxes separated $0,30 \mathrm{~cm}$ horizontally, $0,12 \mathrm{~cm}$ vertically ant in contact in the long dimension of boxes. 
The results of the alculations are presented in Table 6. The first entiy is consistent with the resilts of Table 5 . The second entry represents open bexes at work stations having low demsity water within and between the elusters of four worix locations and herween the stations and the storage locations. The closeby pacted array prevents water between boxes at storage boctions. and the buxes prevent internal moderation of the plates. The third and fourth intries show litte change in reactivity with designated work station joxes filled with water at full density. The wext five eatries show similar results for spaced boxes. The last entry is a repat of the ninth. but with double the water density in the void cells. This is equivalent to moderation at twice the void spacing but with a highei probability of neutron coupling between storage and work bations because the distances have remained constant. The negative effect on the array reactivity is slight and is indicative of the low reactivity of the units with moderalion.

Table 6. Computes k-eff of zoncrete reflected arrays of 912 boxes of plates arrançed: in $10 \times 10 \times$ IC cisbidal array with variable noderating conditions

\begin{tabular}{|c|c|c|c|c|c|c|}
\hline \multirow{3}{*}{$\begin{array}{c}\text { Box } \\
\text { Spacing } \\
0\end{array}$} & \multicolumn{4}{|c|}{$\begin{array}{l}\text { Water Density, } g / c c \text {, at } \\
24 \text { storage Locations } 9 \text { dork Stations } \\
\text { Betwien }\end{array}$} & \multirow{3}{*}{$\begin{array}{c}\text { Empty } \\
\text { Cell's } \\
(83) \\
0\end{array}$} & \multirow{2}{*}{$\begin{array}{c}{[3 \mid c-1 a t=0} \\
\text { iriay } \\
\text { heft }\end{array}$} \\
\hline & PTates & Boxes & Plates & Boxes & & \\
\hline & 0 & 0 & 0.05 & ง & & $C .661=0.005$ \\
\hline 0 & 0 & 0 & 0.0 .5 & 0 & 0.5 & $0.65:=0.0 C=$ \\
\hline 0 & 0 & 0 & 1.0 & 0 & ? & $0.6: 3 \cdot 0.3: 2$ \\
\hline 0 & 0 & 0 & 1.0 & 0 & 0.5 & $0.59^{\circ} \cdot 0.25$ \\
\hline (c) & 0 & 0.05 & 0 & 0.05 & 0 & $0.7: 3.205$ \\
\hline (i) & 0 & 0.05 & 0.05 & 0.05 & 0 & $0 . \because \vdots-9 . \therefore 3$ \\
\hline$(\vdots)$ & 0 & 0 & 0.05 & 0.35 & 0.25 & $0 . \equiv 3 \cdot 2 . \therefore \equiv$ \\
\hline$(\vdots)$ & 0 & 0 & 1.0 & 2.35 & 0.05 & $0 . \approx 2 \cdot \therefore \therefore$ \\
\hline (j) & 0 & 0.05 & $\therefore 0$ & 0 & 0.05 & $0 . \because 2 \cdot 0.006$ \\
\hline$(\vdots)$ & 0 & 0.05 & 1.0 & 0 & $0.1 ?$ & $0.6:=\cdot \therefore: 0$ \\
\hline
\end{tabular}

\section{Compacts}

The $24.765 \mathrm{~g}$ of $\mathrm{V}, \mathrm{O}$. is mixed with $44.95 \mathrm{~g}$ of aluminum; one fuel plate. The mixcure is pressed into compacts hasing dimensions and alom ritumber densilies given in Table 7. 
Table 7. Description of typical HFBR compaz:

\begin{tabular}{|c|c|c|}
\hline \multicolumn{2}{|c|}{ Compositior. } & \multirow{3}{*}{$\begin{array}{l}\text { Dimensions of Compdet, cm } \\
5.5 \times 6.7 \times 0.68\end{array}$} \\
\hline Material & mass. 9 & \\
\hline$U_{3}, 0_{0}$ & 24.765 & \\
\hline Al & 44.950 & \\
\hline \multicolumn{3}{|c|}{ Atom Number Densities: } \\
\hline \multicolumn{2}{|c|}{$233 v=1.99735-3$} & $100=5.712396-3$ \\
\hline \multicolumn{2}{|c|}{$230 U=1.44801-4$} & ${ }^{27} A 1=4.00442-2$ \\
\hline
\end{tabular}

After pressing, 24 compacts are handled as a lot and are placed in a stainless stect tray having a nominal wall thickness of $0.157 \mathrm{~cm}(0.062 \mathrm{in}$.) and inside dimensions $12.7 \times 20.32 \times 7.95 \mathrm{~cm}$. The trays have a lip and nominal outside dimensio.1s of $13.55 \times 21.27 \times 8.26 \mathrm{~cm}$. The compacts are placei in the trays on edge in a $3 \times 8$ arrangement. The trays are normally covered; however, they are assumed in this analysis as uncovered when in sprinklered areas of the plant. The calculated $k_{e ! 1}$ of a :ingle tray and of arrays of trays under various water conditions is reported in Table 8 . The trays containing water at full density are filled. It is clear that, whe.r tiays are protected from accumulating water, as many as 64 , reasonably close-packed. do not present a criticality threat. Sixty-four trays containing compacts and water and reflected by water could result in supercriticality. The initial effect of low density water introduced into a dry array may be regarded as not significant.

Table 8. Calculated $k$-eff of stainless steel trays each conjailing 24 fuel plate compacts arranged in cuboidal arrays reflected by $30.5-r . m-t h i c k$ water

\begin{tabular}{|c|c|c|c|}
\hline $\begin{array}{l}\text { Number of } \\
\text { Trays and } \\
\text { Arrangement }\end{array}$ & $\begin{array}{c}\text { Water } \\
\text { in } \\
\text { Trays }\end{array}$ & $\begin{array}{c}\text { Density, } g / c c, \\
\text { Between } \\
\text { Trays }\end{array}$ & Array k-eff \\
\hline 1 & 0 & $\ldots$ & $0.406=0.005$ \\
\hline \multirow[t]{2}{*}{$8(2 \times 2 \times 2)$} & 1.0 & 0 & $0.715=0.005$ \\
\hline & 1.0 & 0.05 & $0.729: 0.005$ \\
\hline $16(4 \times 2 \times 2)$ & 1.0 & 0 & $0.803 \div 0.006$ \\
\hline \multirow[t]{2}{*}{$32(4 \times 4 \times 2)$} & 1.0 & 0 & $0.867 \cdot 0.005$ \\
\hline & 1.0 & .05 & $0.376 \cdot 0.007$ \\
\hline \multirow[t]{3}{*}{$64(4 \times 4 \times 4)$} & 0 & 0 & $0.542: 0.004$ \\
\hline & 1.0 & 0 & $1.048: 0.008$ \\
\hline & 0.05 & 0.05 & $0.612 \div 0.006$ \\
\hline
\end{tabular}

${ }^{a}$ Trays are in contact in the two horizontal dimensions and separated $5.7 \mathrm{~cm}$ ve: tically. 


\section{Fued elements}

Critical experiments with the HFIR fuel element somponents have demonstrat:d their subcriticality when submerged. A square annulus formed with 12 HFBR or with 12 SPERT-D fuel elements would also be subcritical submerged.

Elements in plant operations are transported and stored on carts which provide a minimum $30-\mathrm{cm}$ surface separation between elements. The carts. however, can be adjacent to a work station allowing a box of plates, for example, to be $15-\mathrm{cm}$ from the surface of the fuel element. Fxamination of the potential for criticality of this situation and to illustrate the $k_{\text {eft }}$ of fuel elements with different degrees of water moderation, two arrays of SPERT-D elements separated by $15.2 \mathrm{~cm}$ were calculated. It is to be remarked that plant practice does provide a shield surrounding the fuel elements which prevents internal moderation. and there is no means by which water would be selectively retained between the fuel plates.

The use of the SPERT-D elements in place of the HFBR elements thus far calculated provides an experimentally measured assembly with a minimum critical mass comparable to the HFBR elements. The square annulus also results in greater neutron coupling between the plane surfaces of the two arrays than would occur with the cylindrical HFIR annuli. Sixteen complete SPERT-D elements (Table 2) are supercritical submurged. A square annulus with 12 elements is formed by removing the center four elements. Neutron interaction is with a second identical array located in a direction perpendicular to the strface of the fuel plates to enhance neutron coupling. The calculations also emploxed a $40.6-\mathrm{cm}$-1 hick concrete floor about $20 \mathrm{~cm}$ from the bottom of the elements. The water density is variable in the region between plates, between arrays. in the ceuters of the syuare annuli, and in the region $7.6 \mathrm{~cm}$ from the nuter lateral surfaces of the arrays. The results of these calculations are given in Table 9. The first three entries have full density water between plates. a condition that is not credible. with increasing water density in the void regions of the arrays. A further increase in water density beyond $1.1 \mathrm{~g}$ ce would result in decoupling the arrays and the $k_{e: l}$ would approach that of a subcritical submerged annulus.

Table 9. Calculated $k$-eff of two neutron interacting assenblies of SPERT-D fuel elements separated by $15 \mathrm{~cm}$

\begin{tabular}{|c|c|c|c|c|}
\hline $\begin{array}{l}\text { Number of } \\
\text { Elements and } \\
\text { Mrrangement }\end{array}$ & $\begin{array}{l}\text { Between } \\
\text { Plates } \\
\end{array}$ & $\begin{array}{c}\text { Density, } \\
\text { Center of } \\
\text { Annulus }\end{array}$ & $\begin{array}{l}m^{3} \\
\text { Outside } \\
\text { Elements }\end{array}$ & $k-e f f$ \\
\hline $\begin{array}{c}12 \text { as } \\
\text { Annulu? }\end{array}$ & $\begin{array}{l}1.0 \\
1.0\end{array}$ & $\begin{array}{l}0.05 \\
0.10\end{array}$ & $\begin{array}{l}0.05 \\
0.10\end{array}$ & $\begin{array}{l}0.439: 0.006 \\
0.520: 0.007\end{array}$ \\
\hline$"$ & $\begin{array}{l}1.0 \\
0.1\end{array}$ & $\begin{array}{l}0.25 \\
0.1\end{array}$ & $\begin{array}{l}0.25 \\
0.1\end{array}$ & $\begin{array}{l}0.699 \cdot 0.009 \\
0.071: 0.002\end{array}$ \\
\hline $\begin{array}{c}16 \text { as } \\
4 \times 4 \text { Array } \\
\text { " }\end{array}$ & $\begin{array}{c}c \\
0.1\end{array}$ & $\begin{array}{c}0^{j} \\
0.1^{j}\end{array}$ & $\begin{array}{l}0.1 \\
0.1\end{array}$ & $\begin{array}{l}0.037: 0.001 \\
0.073: 0.002\end{array}$ \\
\hline$"$ & 1.0 & $1.0^{b}$ & 1.0 & $0.984=0.010$ \\
\hline
\end{tabular}


The fifth through seventh entries would represent a slightly supercritical configuration* submerged and with a thicker reflecto: than described in the cakubtion. Two HFIR outer elements submerged at a $15 \mathrm{~cm}$ separation or in contact are known to be subcritical by experimen:." The arrangements cakulated demonstrate sufficient suberiticality to obviate concern with location of any single element adjacent to work stations or storage array; and because of the low $A_{x i t}$ of elements protected from: water, any number may be permitted.

Additional caiculations reported in Table 10 were performed with HFBR fuel elements. The low density water in the reflected array of the $4 \times 4 \times 1$ arrangement produces greater $k_{\text {ett }}$ s than observed in Table 9 becausr of the closely fitting thick water reflector. Sixteen elements, submerged and spaced at $5.1 \mathrm{~cm}$ surface separation, are subcritical. An infinite planar $2 \times x \times 1$ array with ekments separated $5.1 \mathrm{~cm}$ is also subcritical. These data are useful to support a more efficient operation in the rinsing of HFBR and ORR elements since they would allow more than a sirgle ekment in the rinse tank. For example, six ekements with at least $5.0 \mathrm{~cm}$ between ekment surfaces in any arrangement wciuid be subcritical.

Table 10. Calcu? 1 ted $k$-eff of water reflected arrangements of HFGR fuel elements

\begin{tabular}{|c|c|c|c|}
\hline Array & $\begin{array}{l}\text { angement } \\
\text { Surface } \\
\text { Separation, cm }\end{array}$ & $\begin{array}{l}\text { Water Dersiisy } \\
\text { gicc, in Array }\end{array}$ & $k$-eff \\
\hline $2 \times \times 1$ & 3.1 & 1.0 & $0.772 \div 0.01$ \\
\hline $4 \times 4 \times 1$ & 5.1 & 1.0 & $0.844=0.01$ \\
\hline $\begin{array}{l}4 \times 4 \times 1 \\
4 \times 4 \times 1\end{array}$ & $\begin{array}{l}0.0 \\
0.0\end{array}$ & $\begin{array}{l}0.025 \\
0.050\end{array}$ & $\begin{array}{l}0.547: 0.01 \\
0.570 \div 0.01\end{array}$ \\
\hline $\begin{array}{l}4 \times 4 \cdot 1 \\
4 \times 4 \times 1\end{array}$ & $\begin{array}{l}0.0 \\
0.0\end{array}$ & $\begin{array}{l}0.075 \\
0.10\end{array}$ & $\begin{array}{l}0.584 \div 0.01 \\
0.597 \div 0.01\end{array}$ \\
\hline $\begin{array}{l}12 \text { as } \\
\text { Square } \\
\text { Annulus }\end{array}$ & 0.0 & 1.0 & $0.908 \div 0.005$ \\
\hline
\end{tabular}

- The reactivity coupling of two critical cores at this separation in water can be expected to be less than a few tens of cents." 


\section{Diecussion}

The amalyses performed with compact cubic arrays are an overly conservative approximation of the plant operations. Consider the hargest array of Table + hasing 8000 units and a $k_{:::} \sim 0.9$. The dimensions of the array would be $7.1 \times 12.2 \times 3.6 \mathrm{~m}$ whereas the plant dimensions are of the order of $15.2 \times 80 \times 9 \mathrm{~m}$. If the concrete assumed as a reflector surrounding the cubic array were to be moved from the array to the boundaries of the operations area. the $k_{\text {:it }}$ of the array would decrease to about $80 \%$ of its value. Further. the light building structure and the concrete floor are less effective as a reflector than the $\mathbf{4 0 . 6} \mathrm{cm}$ concrete assumed or thick water. If the cexcrete reflector at the boundaries of the operations area were conserva!ively replaced by a thick water reflector, the $k_{\text {stt }}$ would be further reduced to kss than $85 C_{i c}$ of its value. Thus, the $20^{3}$ array centered in the area would be expected to have a $k_{\text {:: }}$ not exceeding $0.9 \times 0.85 \times 0.8$ or $\sim 0.6$. The number of units in storage. in operations and as fuel elements is less than 500 . Reducing the number from 8000 to jw would cause the $k_{i::}$ to decrease to about 73 ; of its :alue, resulting a $k_{i: 1}$ less than 0.4.

The dispersion of the units thrughhout the operations area would result in at least an additional

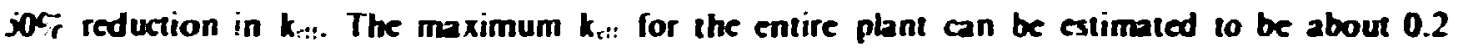
without optimum moderation. The $\Delta \boldsymbol{k}_{r}$ ", from moderation would be some small fraction of the maximum observed in the analysis of the cubic arrays ( 0.4. internal and external to the units). The dispersion of fissionabte materials and the presence of water at optimum density would result in some decoupling of storage arrays and of work locations. It is evident that the likelihood of $k_{\text {ett }}$ exceeding 0.5 is very low.

Operations are conducted in a manner providing protection from internal moderation of fuel elements. of fuel plates in storage. and of compacts in storage. Internal moderation that may occur at individual work stations is of little consequence as the data of Tables 5 and 6 show. It follows that the Cl system can effectively control the nuclear criticality safety under credible normal and abnormal contingencies.

\section{Conclusions}

The calculational results demonstrate that the Cl system does provide criticality control in all operations at the facility. The following may be said of the points addressed in the study:

- Storage arrajs of boxes with 24 plates cach have a larger margin of subcriticality when close-packed than when spaced. The use of aluminum boxes would provide an additional margin of subcriticality.

- A minimum surface separation of $15 \mathrm{~cm}$ between assembled fucl elements and work stations or between elements and storage arra!s provides an ample margin of subcriticality for the variable conditions of moderation and neutron reflection that may occur in operations.

- No additional administrative controls are necessary for the movement of materials. location of storage areas or proximity of several work stations provided the criteria of the $\mathrm{Cl}$ system are met.

- There is no danger of criticality from the sprinkler system nor from hoses with fog noz/les. Immediate action in fighting fires is permissible and would be prudent. 


\section{REFERENCES}

!. 3. T. Thomes, Ed.. Nucker Sofely Guide, TID mI6 Rev. 2. To be putlished.

2. J. K. Fox and L. W. Gilley. Critical Experiments with Arrajs of ORR and BSR Fuel Elements. Neutron Physics Division Annual Progress Report for period ending September 1. 1958. ORNL-2609. Oak Ridge National Laboratory (1958).

3. E. B. johnson and R. K. Reedy, Ir.. Critical Experiments with SPERT-D Fuel Elements. ORNL TM-1207, Oak Ridge National Laboratory (1965).

4. L. M. Petric and N. F. Cross. KenO-IV: An Improved Monte Corb Criticality Program. ORNL 4938. Onk Ridge National Laboratory (1975).

5. G. E. Hansen and W. H. Roach, Six and Sixteen Group Cross Sertions for Fast and Intermediate Critical Assemblies, LAMS-2543. Los Alamos Scientific I aboratory (1961).

6. N. M. Greene, et al., AMPX: A Modular Code System for Generating Coupled Multizroup Neutron-Gamm Libraries from ENDF/ B, ORNL, TM-3706. Oak Ridge National Laboratory (1976).

7. E. B. Johnson. Critical Lattices of High Flux Isotope Reactor Fuel Elements. ORNL TM-1808. Oak Ridge National Laboratory (1967).

8. S. J. Raffety and J. T. Thomas, Experimentel Determination of Soff Handling Procedures for High Flux Isotope Reactor Fuel Elements Outside the Reactor. OR.NL TM-1488. Oak Ridge National Laboratory (1966). 